\title{
Phenolic Resin-coated Porous Silicon/carbon Microspheres Anode Materials for Lithium-ion Batteries
}

Jingli Liu ( $\sim 18332692857 @ 163 . c o m$ )

Jishou University https://orcid.org/0000-0003-2214-4745

Xian-ming Wu

Jishou University

Shang Chen

Jishou University

Rui-lai Long

Jishou University

Cai shuo Yin

Jishou University

\section{Feng Zhang}

Jishou University

\section{Research Article}

Keywords: micro-sized, porous silicon/carbon microspheres, Li-ion batteries

Posted Date: April 19th, 2021

DOI: https://doi.org/10.21203/rs.3.rs-362558/v1

License: () (1) This work is licensed under a Creative Commons Attribution 4.0 International License. Read Full License

Version of Record: A version of this preprint was published at Silicon on July 19th, 2021. See the published version at https://doi.org/10.1007/s12633-021-01240-y. 
Phenolic resin-coated porous silicon/carbon microspheres anode materials for Lithium-ion batteries

Liu Jing-li1 ${ }^{1}$ Wu Xian-ming ${ }^{1} \cdot$ Chen shang $^{1} \cdot$ Long Rui-lai $^{1} \cdot$ Yin Cai-shuo ${ }^{1} \cdot$ Zhang Feng $^{1}$

(1 College of Chemistry and Chemical Engineering, Jishou University, Jishou 416000, Hunan, China

$\bowtie$ Liu Jing-li 18332692857@163.comＯRCID: 0000-0003-2214-4745)

\section{Abstract}

Porous silicon/carbon (Si/C) anode materials for Lithium-ion batteries was synthesized successfully by hydrochloric acid etching and calcination method using micron $\mathrm{Si}-\mathrm{Al}$ alloy as silicon source and phenolic resin as carbon source. The microstructure and morphology were characterized by XRD, SEM, TEM, XPS and BET. The electrochemical performance were measured by constant current chargedischarge test and EIS. The results show that $\mathrm{Si} / \mathrm{C}$ is porous structure and its pores are distributed between 1-6 nm. The specific discharge specific capacity of $\mathrm{Si} / \mathrm{C}$ is $1287.0 \mathrm{mAh} / \mathrm{g}$ at a current density of 100 $\mathrm{mA} / \mathrm{g}$ after 50 cycles, corresponding to the capacity retention of $91.0 \%$ (for the second cycle). $\mathrm{Si} / \mathrm{C}$ delivers a high specific discharge capacity of 605.9 and $359.0 \mathrm{mAh} / \mathrm{g}$ at $1 \mathrm{~A} / \mathrm{g}$ and $2 \mathrm{~A} / \mathrm{g}$, respectively. The lithium ion diffusion coefficient of $\mathrm{Si} / \mathrm{C}$ is $5.98 \times 10^{-11} \mathrm{~cm}^{2} \mathrm{~s}^{-1}$, which is higher than that of $7.57 \times 10^{-}$ $12 \mathrm{~cm}^{2} \mathrm{~s}^{-1}$ for porous $\mathrm{Si}$.

Keywords micro-sized $\cdot$ porous silicon/carbon microspheres $\cdot$ Li-ion batteries

\section{Declarations}

Funding: Xiangxi Ores Minerals and New Materials Development and Service Center, Jishou 416000, Hunan, China

Conflict of Interest: Not applicable

Author contributions: Provision of paper data, research ideas and designers, article writer

Availability of data and material: The data sets supporting the results of this article are included within the article and its additional files.

Compliance with ethical standards: This article does not contain any studies with human participants performed by any of the authors.

Consent to participate: Consent.

Consent for Publication: Consent.

Acknowledgments: This work was supported by the National Natural Science Foundation of China. 


\section{Introduction}

In recent years, Silicon has been widely concerned as a lithium-ion battery anode material due to its large specific capacity $(\sim 3579 \mathrm{mAh} / \mathrm{g})$, low discharge potential $\left(\sim 0.4 \mathrm{~V}\right.$ versus $\left.\mathrm{Li} / \mathrm{Li}^{+}\right)$ and natural abundant[1-4]. However, the silicon has a dramatic volume expansion $(\sim 300 \%)$ during charging and discharging, which resulting in cracking and pulverization, losing of electrical contact, and forming unstable solid electrolyte interface (SEI) films, eventually leading to capacity attenuation[5-8]. To overcome these defects, many measures have been tried, such as nanostructure design[9-12], doping[13-15] and carbon coating[16-21].

Porous silicon can shorten the lithium-ion diffusion path, alleviate the bulk expansion effect and improve the electrochemical performance[22,23] because of its $3 \mathrm{D}$ pore structure. The coated carbon layer on the porous silicon not only provides buffer for the volume expansion of silicon, but also enhances the electrical conductivity of the material[24-30]. Based on above considerations, $\mathrm{Si} / \mathrm{C}$ composite was prepared by hydrochloric acid etching and calcination method using micron $\mathrm{Si}-\mathrm{Al}$ alloy as silicon source and phenolic resin as carbon source in this paper.

\section{Experimental}

$\mathrm{Al}-\mathrm{Si}$ alloy particle with the average size of around $2 \mu \mathrm{m}$ were added in $4 \%$ hydrochloric acid solution, and mechanical stirred in a water bath at $40^{\circ} \mathrm{C}$ for 12 hours, followed by rinsing with deionized water until neutral. Then the powder was placed in a vacuum drying oven at $80{ }^{\circ} \mathrm{C}$ for $40 \mathrm{~min}$ to prepare porous silicon.

Phenolic resin was added to anhydrous ethanol and stirred at $40^{\circ} \mathrm{C}$ until it dissolved completely. Then different amounts of porous silicon was added into the solution and stirred for $4 \mathrm{~h}$, then dried in a vacuum at $80{ }^{\circ} \mathrm{C}$ for $40 \mathrm{~min}$ to remove the solvent. The mixture was annealed at $850{ }^{\circ} \mathrm{C}$ for $4 \mathrm{~h}$ in $\mathrm{Ar}$ atmosphere to obtain $\mathrm{Si} / \mathrm{C}$ composite with mass ratio of $1: 2$ ( $\mathrm{Si}: \mathrm{C}=1: 2)$, which is labeled as $\mathrm{Si} / \mathrm{C}$.

Weight loss process of phenolic resin was characterized by thermogravimetric analysis (TGA). The phase was determined by X-ray diffraction (XRD) from $10^{\circ}$ to $80^{\circ}$. Morphologies were observed by scanning electron microscopy (SEM) and transmission electron microscopy (TEM). $\mathrm{N}_{2}$ adsorption/desorption measurements of the samples were evaluated with the BrunauerEmmett-Teller (BET) method. X-ray photoelectron spectroscopy (XPS) measurements were applied to analyze the surface elemental composition and valence states of the samples. Active substances $(\mathrm{Si} / \mathrm{C})$, acetylene black and binder PVDF were dissolved in n-methyl pyrrolidone solvent at a mass ratio of $8: 1: 1$ to 
obtain slurry. The slurry was evenly coated on the $\mathrm{Cu}$ foil and dried under vacuum at $60{ }^{\circ} \mathrm{C}$ for $4 \mathrm{~h}$. After drying, take out the sheet and cut it into an electrode with diameter $(\mathrm{d})=14 \mathrm{~mm}$. The assembly of CR2023-type cell with lithium sheet as negative electrode was conducted in a glove box filled with argon. Microporous polypropylene film as the diaphragm, and $1 \mathrm{M}$ LiPF6 [V (EMC):V(EC):V(DMC)=1:1:1] was employed as electrolyte.

\section{Results and discussion}

Fig.1 is thermogravimetric(TGA) curve of $\mathrm{Si} / \mathrm{C}$ precursor. As shown in the figure, the main weight loss occurs from $320^{\circ} \mathrm{C}$ to $850{ }^{\circ} \mathrm{C}$, which can be attributed to the pyrolysis of phenolic resin. After that, the weight of $\mathrm{Si} / \mathrm{C}$ precursor does not change with temperature, indicating that the reaction is roughly complete. Therefore, $850{ }^{\circ} \mathrm{C}$ is chosen as carbonized temperature. According to TGA curve, the carbon contents in the $\mathrm{Si} / \mathrm{C}$ composite can be calculated to be $30.8 \mathrm{wt} \%$, which is in accordance with the amount of silicon added to the reaction.

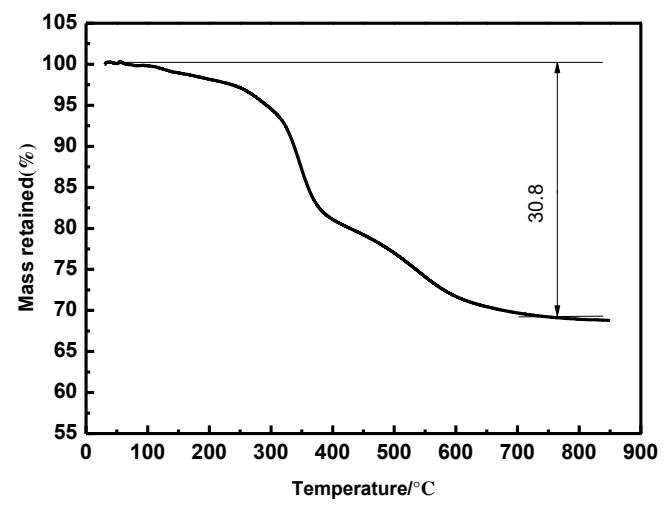

Fig. 1 TG curves of the as-prepared Si/C composite

The X-ray diffraction pattern of porous silicon and $\mathrm{Si} / \mathrm{C}$ composite are shown in Fig. 2. As seen in the figure, all of the diffraction peaks can be assigned to the standard peaks of $\mathrm{Si}$ according to the PDF card (27-1402). The peaks appeared at $28.5^{\circ}, 47.4^{\circ}, 56.2^{\circ}, 69.3^{\circ}$ and $76.5^{\circ}$, corresponding to the (111), (220), (311), (400) and (331) diffraction planes, respectively. The diffraction peaks of porous silicon are sharper than those of $\mathrm{Si} / \mathrm{C}$, which is due to the carbon coating on the surface of Si. No diffraction peaks of carbon are observed in the samples, suggesting that the carbon is amorphous.

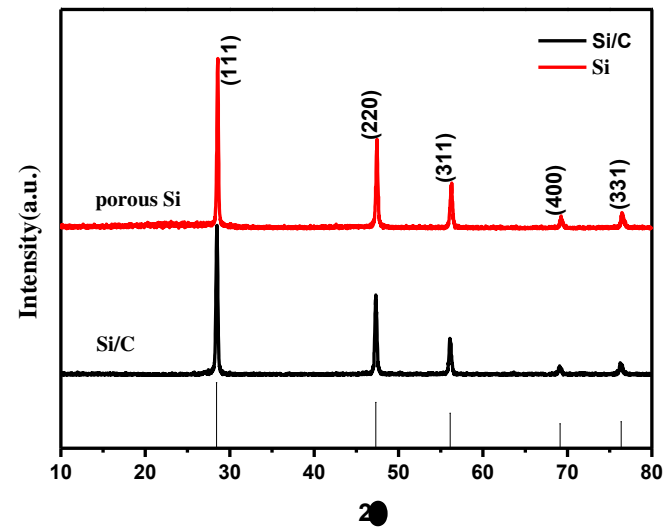

Fig. 2 XRD patters of the porous silicon and

$$
\mathrm{Si} / \mathrm{C} \text { composite }
$$

The scanning electron micrographs (SEM) of porous $\mathrm{Si}$ and $\mathrm{Si} / \mathrm{C}$ composite are displayed in Fig. 3. As shown in the Fig. 3a, micro-sized porous $\mathrm{Si}$ is spherical and dispersed evenly. It can be clearly seen that there are many nano pores in porous $\mathrm{Si}$, indicating that the porous $\mathrm{Si}$ has a good 
porous structure. The $\mathrm{Si} / \mathrm{C}$ composite is demonstrated in Fig. 3b, the porous silicon is covered by a dense carbon layer formed by the pyrolysis of phenolic resin, which can restrain the expansion of macro-porous $\mathrm{Si}$ and improve the conductivity of material.
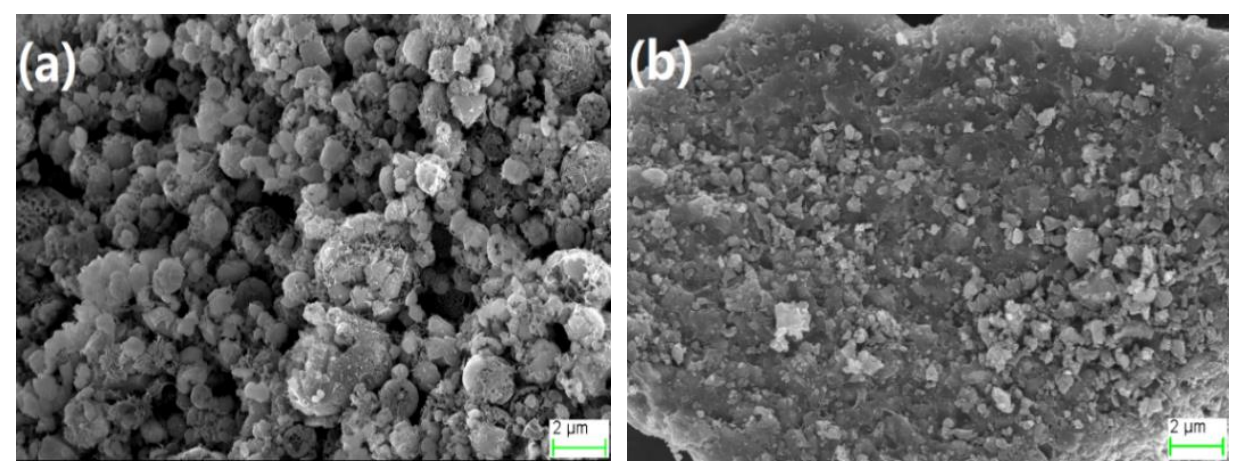

Fig. 3 The scanning electron microscopy of porous $\mathrm{Si}$ and $\mathrm{Si} / \mathrm{C}$ : (a) porous $\mathrm{Si}$; (b) $\mathrm{Si} / \mathrm{C}$
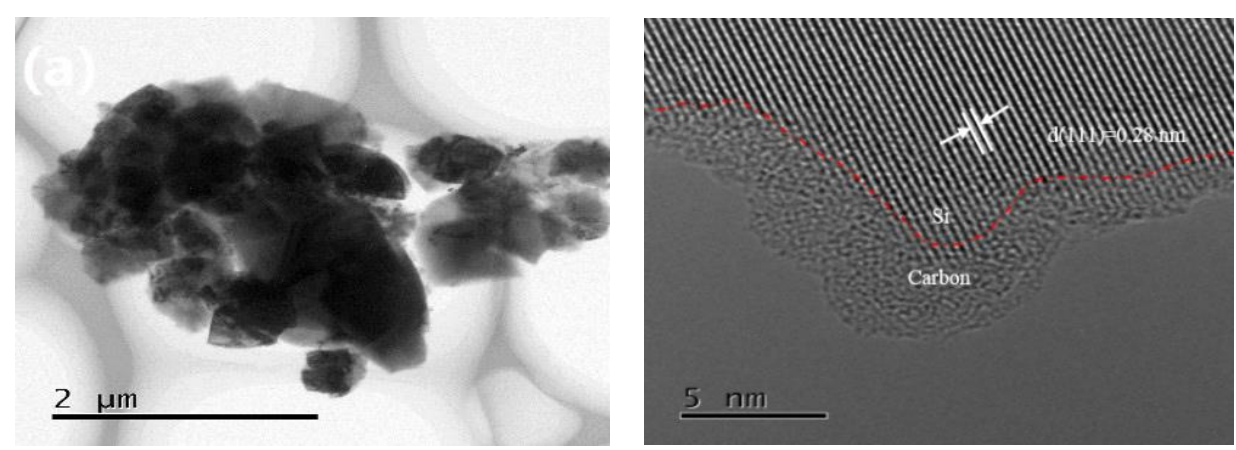

Fig. 4 transmission electron micrographs images of Si/C

Figure 4 is the microstructure and morphology of $\mathrm{Si} / \mathrm{C}$ and by transmission electron microscopy (TEM). As show in the figure, $\mathrm{Si}$ particle is uniformly coated by a carbon layer, which is beneficial to the structural stability of the material during the insertion/extraction of lithium-ion. The carbon layer can also prevent the formation of unstable SEI film due to silicon particle fragmentation and exposure to electrolyte. In addition, $\mathrm{Si} / \mathrm{C}$ composite has good crystallinity and the lattice stripe spacing of $0.28 \mathrm{~nm}$ can be clearly observed and verified to be the characteristic (111) crystal plane of Si.
Figure 5 is the $\mathrm{N}_{2}$ adsorption-desorption isotherms of $\mathrm{Si} / \mathrm{C}$ composite. The adsorption/desorption curves (Fig. 5a) show that the late hysteresis loop in the relative pressure $\mathrm{P} / \mathrm{P}_{0}$ of $0.8-1.0$, indicating its macroporous structure. Meanwhile, the corresponding pore size distributions of the samples (Fig. 5b) were analyzed by the Density Functional Theory (DFT) method. It shows that the pores of the $\mathrm{Si} / \mathrm{C}$ are mainly centered at around 1-6 nm. The proper specific surface area and pore size distribution are helpful for the penetration and promotion of the electrolyte, which can shorten the lithium-ion 
transport channel and increase the active reaction sites.

Figure 6 is the X-ray photoelectron spectroscopy (XPS) analysis of $\mathrm{Si} / \mathrm{C}$ composite. As seen in the Fig. 6a, diffraction peaks of silicon, oxygen and carbon are observed in the $\mathrm{Si} / \mathrm{C}$ composite. The Si 2p XPS spectrum in Fig. 5b can be fitted with three positions: the Si $2 p$ (Fig. 6b) characteristic peaks centered at $103.1 \mathrm{eV}$ for $\mathrm{Si}-\mathrm{O}$ bond, $101.9 \mathrm{eV}$ for $\mathrm{Si}-\mathrm{C}$ bond and $98.6 \mathrm{eV}$ for $\mathrm{Si}-$
Si bond. The C 1s (Fig. 6c) characteristic peaks appear at $284.8 \mathrm{eV}, 286.3 \mathrm{eV}$ and $288.8 \mathrm{eV}$, corresponding to the $\mathrm{C}-\mathrm{C}$ bond, $\mathrm{C}-\mathrm{O}$ bond and $\mathrm{C}=\mathrm{O}$ bond, respectively, which is formed during the pyrolysis of phenolic resin. The O 1s (Fig. 6d) peak can be deconvoluted into two components ascribed to $\mathrm{SiO}$ at $533.2 \mathrm{eV}, \mathrm{SiO} 2$ at $531.6 \mathrm{eV}$, which are formed at high temperatures during carbonization process.
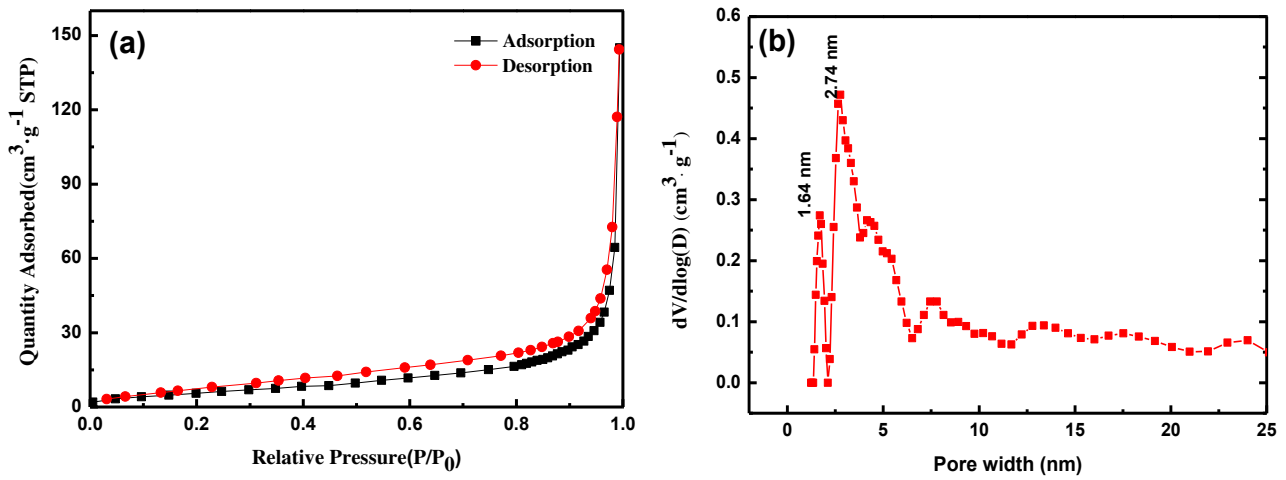

Fig. 5 BET specific surface area test of $\mathrm{Si} / \mathrm{C}$ composite (a) $\mathrm{N}_{2}$ adsorption-desorption isotherms;(b)

DFT pore size distribution
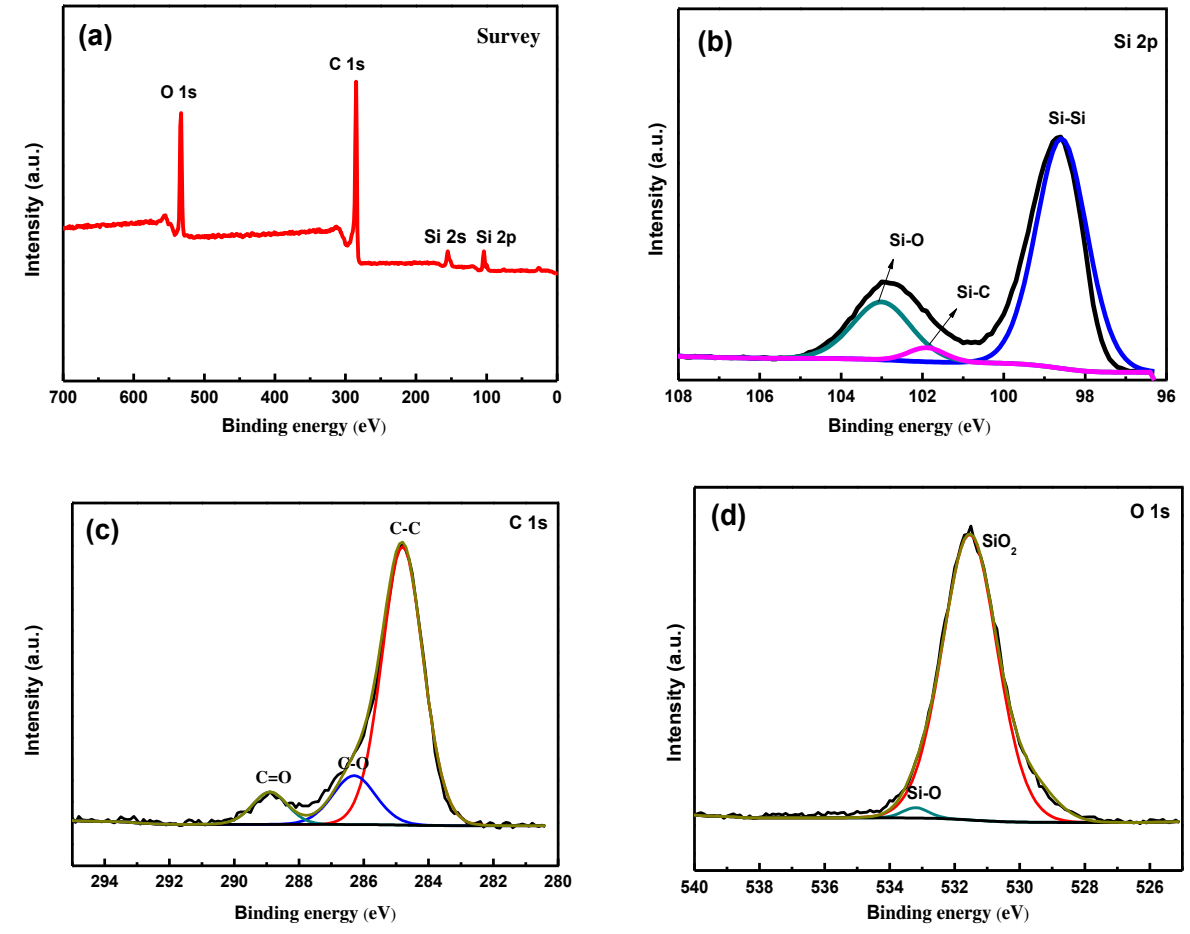
Fig. 6 XPS spectra of porous $\mathrm{Si}$ and $\mathrm{Si} / \mathrm{C}$ : (a)XPS spectra of porous $\mathrm{Si}$ and $\mathrm{Si} / \mathrm{C}$; (b) Si 2 p peaks of $\mathrm{Si} / \mathrm{C}$; (c) C 1 s peaks of $\mathrm{Si} / \mathrm{C}$; (d) O 1 s peaks of $\mathrm{Si} / \mathrm{C}$ peaks of $\mathrm{Si} / \mathrm{C}$

The charge and discharge curves and the cycling performance of porous $\mathrm{Si}$ and $\mathrm{Si} / \mathrm{C}$ at the current density of $100 \mathrm{~mA} / \mathrm{g}$ are displayed in Fig. 7. As seen in Fig.7a, the charge and discharge specific capacities of porous $\mathrm{Si}$ are 1589.0 and $2639.6 \mathrm{mAh} / \mathrm{g}$ in the first cycle with the initial coulombic efficiency of $60.2 \%$, while $\mathrm{Si} / \mathrm{C}$ are 1306.2 and $2048.9 \mathrm{mAh} / \mathrm{g}$ with the initial coulombic efficiency is 63.8\% . As seen in Fig.7b, The irreversible capacity in the initial cycle is mainly due to electrolyte consumption for the formation of the SEI layer on the electrode surface. The specific capacity of Si and $\mathrm{Si} / \mathrm{C}$ are 192.1 and $1287.0 \mathrm{mAh} / \mathrm{g}$ after 50 cycles, corresponding to the capacity retention of $12.1 \%$ and $91.0 \%$ for the second cycle. The capacity loss is mainly related to the dramatic volume expansion, structural fracture and loss of electrical contact during the cycling process. While the coating carbon helps to restrain the bulk expansion effect of Si and enhance the electrical conductivity of the composite. As a result, $\mathrm{Si} / \mathrm{C}$ has a higher reversible specific capacity and smaller capacity fluctuation than that of $\mathrm{Si}$ during the process of 50 cycles.
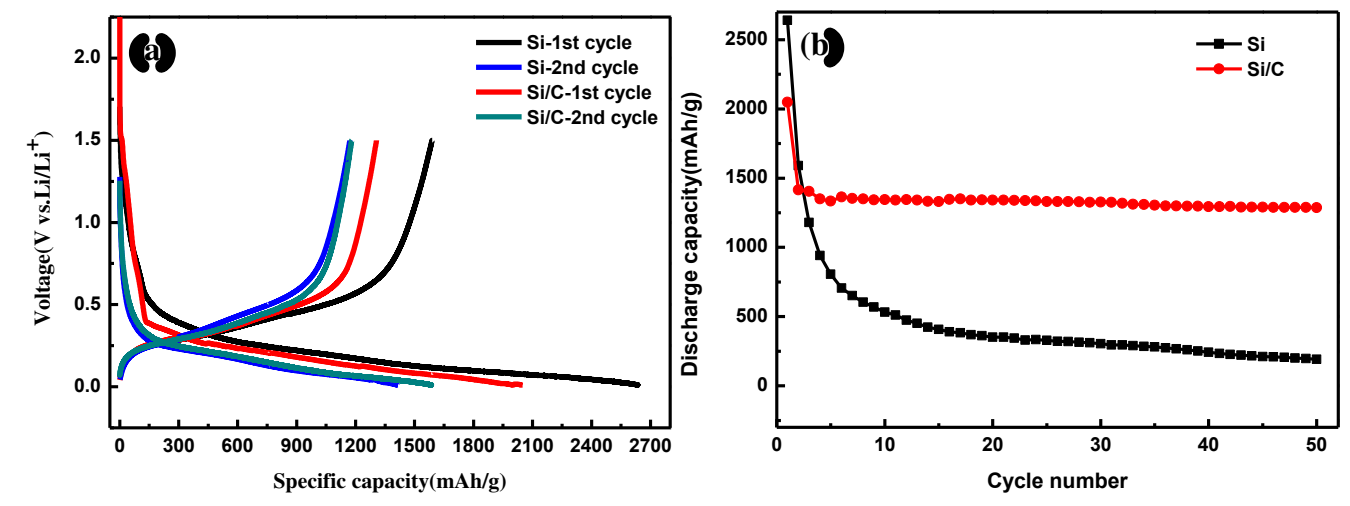

Fig. 7 The electrochemical performances of porous $\mathrm{Si}$ and $\mathrm{Si} / \mathrm{C}$ at the current density of $0.1 \mathrm{~A} / \mathrm{g}$. (a) charge-discharge curves; (b) cycling performance

The cycling performances of porous $\mathrm{Si}$ and $\mathrm{Si} / \mathrm{C}$ at different current densities are presented in Fig.8. As seen in the figure, $\mathrm{Si} / \mathrm{C}$ delivers a high specific discharge capacity of $1441.4,887.1$, 793.5, 605.9 and $359.0 \mathrm{mAh} / \mathrm{g}$, with the current density increasing from $100 \mathrm{~m} / \mathrm{g}$ to $200 \mathrm{~mA} / \mathrm{g}$, $500 \mathrm{~mA} / \mathrm{g}, 1 \mathrm{~A} / \mathrm{g}$ and $2 \mathrm{~A} / \mathrm{g}$, corresponding to
$95.3 \%, 98.3 \%, 94.3 \%, 91.6 \%$ and $79.8 \%$ capacity retention after 10 cycles. While the charge specific capacities of porous Si are 1683.1, 420.5, $132.5,0.6$ and $0.6 \mathrm{mAh} / \mathrm{g}$ at the same current densities. The discharge specific capacity of $\mathrm{Si} / \mathrm{C}$ and porous Si are 761.4 and $390.4 \mathrm{mAh} / \mathrm{g}$ when current density return to $100 \mathrm{~mA} / \mathrm{g}$, respectively, 
corresponding to $98.8 \%$ and $70.1 \%$ capacity retention after 10 cycles. The huge capacity differences between porous $\mathrm{Si}$ and $\mathrm{Si} / \mathrm{C}$ is due to the particles are crushed by volume expansion and fall off the collector, thus losing electrical contact. Carbon layer in the $\mathrm{Si} / \mathrm{C}$ composites can protect the porous $\mathrm{Si}$ from extensive exposure to the electrolyte and buffer the volume expansion of the active material during the charge/discharge process, resulting excellent cycling stability.

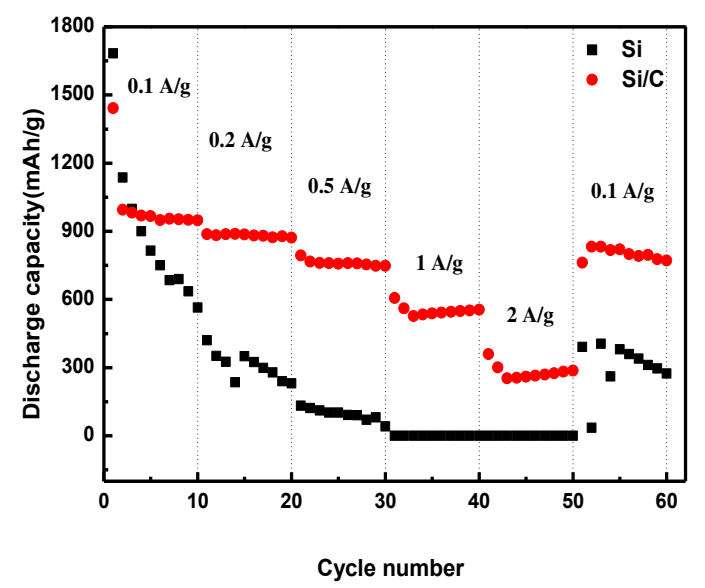

Fig. 8 The cycling performances of porous

$\mathrm{Si}$ and $\mathrm{Si} / \mathrm{C}$ at different charge-discharge rates

The impedance curve and equivalent circuit fitting of porous $\mathrm{Si}$ and $\mathrm{Si} / \mathrm{C}$ are shown in Fig. 9a. As displayed in the figure, The Nyquist plots of the two samples are composed of a circle in the middle and high frequency region and a slash in the low frequency region. The semi-circle represents the charge transfer impedance $R_{c t}$, reflecting the speed of Faraday dynamics. The straight line represents Warburg impedance $\left(R_{w}\right)$ and reflects the diffusion ability of lithium-ions in the electrode material. It is found that the fitting charge transfer impedance of $\mathrm{Si} / \mathrm{C}$ is $74.9 \Omega$, which is much smaller than that of $246.1 \Omega$ for $\mathrm{Si}$. The relationship between $\omega^{-0.5}$ and $Z^{\prime}$ are presented in Fig. 9b. Based on this relationship, Li-ion diffusion coefficient $\left(D_{L i}\right)$ can be calculated from the following equation $[31,32]$.

$$
D_{L i}=R^{2} T^{2} / 2 A F^{4} C^{2} \sigma^{2}
$$

where $R$ is the gas constant $\left(8.314 \mathrm{~J} \cdot \mathrm{mol}^{-1} \cdot \mathrm{K}^{-1}\right), T$ is the absolute temperature $(298 \mathrm{~K}), A$ is the surface area of the electrode $\left(1.54 \mathrm{~cm}^{2}\right), n$ is the number of electrons per molecule during oxidization(1), $F$ is the Faraday constant(96485 $\left.\mathrm{C} \cdot \mathrm{mol}^{-1}\right), C$ is the $\mathrm{Li}^{+}$concentration $\left(4.37 \times 10^{-3}\right.$ $\left.\mathrm{mol} \cdot \mathrm{cm}^{-3}\right)[33]$. According to the above equation, the values of $\mathrm{Li}^{+}$diffusion coefficient of porous $\mathrm{Si}$ and $\mathrm{Si} / \mathrm{C}$ are $7.57 \times 10^{-12} \mathrm{~cm}^{2} \mathrm{~s}^{-1}$ and $5.98 \times 10^{-11}$ $\mathrm{cm}^{2} \cdot \mathrm{s}^{-1}$, respectively. The Li-ion diffusion coefficient of $\mathrm{Si} / \mathrm{C}$ is nearly ten times as porous $\mathrm{Si}$, which can be attributed to the presence of the carbon layer, which makes the pore structure of silicon complete during the charging/discharging, so that the Li-ion could transfer fast through the interlayer path. 

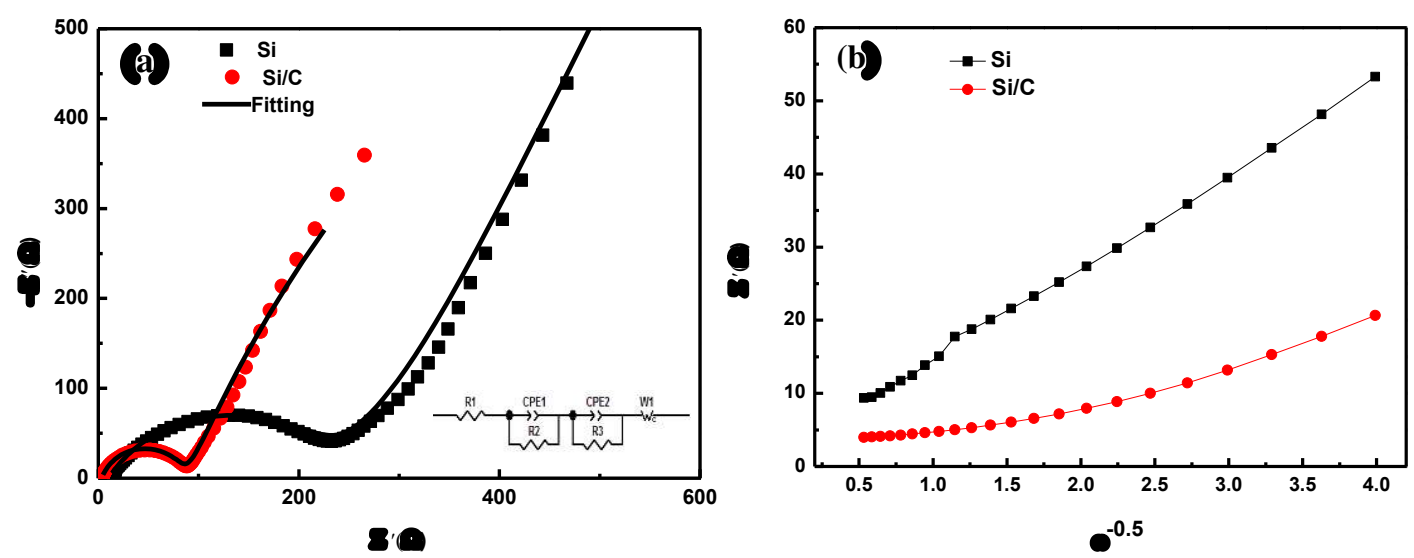

Fig. 9 Electrochemical impedance spectra of porous $\mathrm{Si}$ and Si/C. (a) EIS curves of porous Si and $\mathrm{Si} / \mathrm{C}$; (b) the relationship of $Z^{\prime}$ and $\omega^{-0.5}$

\section{Conclusions}

porous silicon/carbon composite was synthesized by hydrochloric acid etching and calcination method using micron $\mathrm{Si}-\mathrm{Al}$ alloy as silicon source and phenolic resin as carbon source. The prepared $\mathrm{Si} / \mathrm{C}$ has good pore structure and its pores are distributed between 1-6 $\mathrm{nm}$. The specific capacity of porous $\mathrm{Si}$ and $\mathrm{Si} / \mathrm{C}$ are 192.1 and $1287.0 \mathrm{mAh} / \mathrm{g}$ at $0.1 \mathrm{~A} / \mathrm{g}$, corresponding to the capacity retention of $12.1 \%$ and $91.0 \%$ for the second cycle after 50 cycles. Si/C delivers a high specific discharge capacity of 605.9 and 359.0 $\mathrm{mAh} / \mathrm{g}$ at $1 \mathrm{~A} / \mathrm{g}$ and $2 \mathrm{~A} / \mathrm{g}$, corresponding to $91.6 \%$ and $79.8 \%$ capacity retention after 10 cycles. Si/C has a smaller charge transfer impedance than porous Si and a higher Li-ion diffusion coefficient of $5.98 \times 10^{-11} \mathrm{~cm}^{2} \mathrm{~s}^{-1}$ than that of $7.57 \times 10^{-12} \mathrm{~cm}^{2}$ $\mathrm{s}^{-1}$ for the latter.

\section{References}

1. Guo R, Zhang S, Ying H, Yang W, Wang
J, Han WQ (2019) New, Effective, and Low-Cost Dual-Functional Binder for Porous Silicon Anodes in Lithium-Ion Batteries. ACS applied materials \& interfaces 11 (15):1405114058. doi:10.1021/acsami.8b21936

2. Zhang J, Chen Y, Chen X, Feng T, Yang P, An M (2020) Preparation of graphene-like carbon attached porous silicon anode by magnesiothermic and nickel-catalyzed reduction reactions. Ionics 26 (12):5941-5950. doi:10.1007/s11581-020-03746-8

3. Zhang H, Xu H, Jin H, Li C, Bai Y, Lian K (2017) Flower-like carbon with embedded silicon nano particles as an anode material for $\mathrm{Li}$-ion batteries. RSC Advances 7 (48):30032-30037. doi:10.1039/c7ra03576d

4. Yin Y, Arca E, Wang L, Yang G, Schnabel M, Cao L, Xiao C, Zhou H, Liu P, Nanda J, Teeter G, Eichhorn B, Xu K, Burrell A, Ban C (2020) Nonpassivated Silicon Anode Surface. ACS 
applied materials \& interfaces 12 (23):2659326600. doi:10.1021/acsami.0c03799

5. Guan P, Li J, Lu T, Guan T, Ma Z, Peng Z, Zhu X, Zhang L (2018) Facile and Scalable Approach To Fabricate Granadilla-like Porous-Structured Silicon-Based Anode for Lithium Ion Batteries. ACS applied materials \& interfaces 10 (40):34283-34290. doi:10.1021/acsami.8b12071 6. Wang CM, Li X, Wang Z, Xu W, Liu J, Gao F, Kovarik L, Zhang JG, Howe J, Burton DJ, Liu Z, Xiao X, Thevuthasan S, Baer DR (2012) In situ TEM investigation of congruent phase transition and structural evolution of nanostructured silicon/carbon anode $f$ or lithium ion batteries. Nano Lett 12 (3):1-6 24-1632. doi:10.1021/n1204559u

7. Tesfaye AT, Gonzalez R, Coffer JL, Djenizian T (2015) Porous Silicon Nanotube Arrays as Anode Material for Li-Ion Batteries. ACS applied materials \& interfaces 7 (37):20495-20498. doi:10.1021/acsami.5b05705

8. Wang J, Wang C, Zhu Y, Wu N, Tian W (2014) Electrochemical stability of optimized $\mathrm{Si} / \mathrm{C}$ composites anode for lithium-ion batteries. Ionics 21 (2):579-585. doi:10.1007/s11581-014-1331-9 9. Ge M, Lu Y, Ercius P, Rong J, Fang X, Mecklenburg M, Zhou C (2014) Large-scale fabrication, 3D tomography, and lithium-ion battery application of porous silicon. Nano letters 14 (1):261-268. doi:10.1021/n1403923s
10. Guo S, Hu X, Hou Y, Wen Z (2017) Tunable Synthesis of Yolk-Shell Porous Silicon@Carbon for Optimizing Si/C-Based Anode of Lithium-Ion Batteries. ACS Appl Mater Interfaces 9 (48):42084-42092. doi:10.1021/acsami.7b13035 11. Li S, Qin X, Zhang H, Wu J, He Y-B, Li B, Kang F (2014) Silicon/carbon composite microspheres with hierarchical core-shell structure as anode for lithium ion batteries. Electrochemistry Communications 49:98-102. doi:10.1016/j.elecom.2014.10.013

12. Xi F, Zhang Z, Wan X, Li S, Ma W, C -hen X, Chen R, Luo B, Wang L (2020) High-Performance Porous Silicon/Nanosilver Anodes from Industrial Low-Grade Silicon for Lithium-Ion Batteries. ACS applied materials \& interfaces 12 (43):49080-49089. doi:10.1021/acsami.0c14157

13. Liu X, Wang Z, Guo H, Li X, Zhou R, Zhou Y (2017) Chitosan: A N-doped carbon source of silicon-based anode material for lithium ion batteries. Ionics 23 (9):2311-2318. doi:10.1007/s11581-017-2073-2

14. Shen K, Chen H, Hou X, Wang S, Qin H, Gao Y, Shen J (2020) Mechanistic insigh$\mathrm{t}$ into the role of $\mathrm{N}$-doped carbon matrix in electrospun binder-free Si@C composite anode for lithium-ion batteries. Ionics 26 (7):3297-3305. doi:10.1007/s11581-020-03484-x 15. Zhang H, Xu H, Lou X, Jin H, Zong P, Li S, 
Bai Y, Ma F (2019) Micro-structured Si@Cu3Si@C ternary composite anodes for high-performance Li-ion batteries. Ionics 25 (10):4667-4673. doi:10.1007/s11581-019-03043Z

16. Zhang X, Zhou L, Huang M, Yang C, Xu Y, Huang J (2018) Synthesis of porous $\mathrm{Si} / \mathrm{C}$ by pyrolyzing toluene as anode in lithium-ion batteries with excellent lithium storage performance. Ionics $25 \quad$ (5):2093-2102. doi:10.1007/s11581-018-2601-8

17. Zhou R, Fan R, Tian Z, Zhou Y, Guo H, Kou L, Zhang D (2016) Preparation and characterization of core-shell structure $\mathrm{Si} / \mathrm{C}$ composite with multiple carbon phases as an ode materials for lithium ion batteries. Journal of Alloys and Compounds 658:91-97. doi: 10.1016/j.jallcom.2015.10.217

18. Xu R, Zhang K, Wei R, Yuan M, Zhang Y, Liang F, Yao Y (2019) High-capacity flour-based nano-Si/C composite anode materials for lithium-ion batteries. Ionics 26 (1):1-

11. doi:10.1007/s11581-019-03224-W

19. Xu Q, Li J-Y, Sun J-K, Yin Y-X, Wan L-J, Guo Y-G (2017) Watermelon-Inspired Si/C Microspheres with Hierarchical Buffer Structures for Densely Compacted Lithium-Ion Battery Anodes. Advanced Energy Materials 7 (3):1601481. doi:10.1002/aenm.201601481

20. Deng Y, Kang T, Ma Z, Tan X, Song X, Wang
Z, Pang P, Shu D, Zuo X, Nan J (2019) Safety influences of the $\mathrm{Al}$ and $\mathrm{Ti}$ elements modified LiCoO2 materials on $\mathrm{LiCoO} 2 /$ graphite batteries under the abusive conditions. Electrochimica Acta 295:703-709

21. Wang J, Zhang L, Zhang H (2018) Effects of electrolyte additive on the electrochemical performance of $\mathrm{Si} / \mathrm{C}$ anode for lithiumion batteries. Ionics 24 (11):3691-3698. doi: $10.1007 / \mathrm{s} 11581-018-2682-4$

22. Ge M, Rong J, Fang X, Zhou C (2012) Porous doped silicon nanowires for lithium ion battery anode with long cycle life. Nano letters 12 (5):2318-2323. doi:10.1021/n1300206e

23. Yan L, Yong W, Zou Y, Zheng J, Wu M (2010) Macroporous Co $3 \mathrm{O} 4$ platelets with excellent rate capability as anodes for lithium ion batteries. Electrochemistry Communications 12 (1):101105 24. Tang J, Dysart AD, Kim DH, Saraswat R, Shaver GM, Pol VG (2017) Fabrication of Carbon/Silicon Composite as Lithium-ion Anode with Enhanced Cycling Stability. Electrochimica Acta 247:626-633. doi:10.1016/j. electacta.2017.06.178

25. Su M, Wang Z, Guo H, Li X, Huang S, Gan L (2013) Silicon, flake graphite and phenolic resin-pyrolyzed carbon based $\mathrm{Si} / \mathrm{C}$ composites as anode material for lithium-ion batteries. Advanced Powder Technology 24 (6):921-925. doi:10.1016/j.apt.2013.01.002 
26. Luo J, Ma B, Peng J, Wu Z, Luo Z, Wang X (2019) Modified Chestnut-Like Structure Silicon Carbon Composite as Anode Material for Lithium-Ion Batteries. ACS Sustainable Chemistry \& Engineering 7 (12):10415-10424. doi:10.1021/acssuschemeng.9b00616

27. Liang J, Zhang Z, Yang W, Liu Y, Zhang X, Javid M, Jung Y, Dong X (2020) Threedimensional porous carbon skeleton supporting $\mathrm{Si}$ nanosheets as anode for high-performance lithium ion batteries. Ionics 26 (5):2233-2245. doi:10.1007/s11581-019-03409-3

28. Kwon HJ, Hwang JY, Shin HJ, Jeong M G, Chung KY, Sun YK, Jung HG (2020) Nano/Microstructured Silicon-Carbon Hybrid Composite Particles Fabricated with Corn Starch Biowaste as Anode Materials for Li-Ion Batteries. Nano letters 20 (1):625-635. doi:10. 1021/acs.nanolett.9b04395

29. Jaumann T, Herklotz M, Klose M, Pinkert K, Oswald S, Eckert J, Giebeler L (2014) Tailoring Hollow Silicon-Carbon Nanocomposites As High-Performance Anodes in Secondary Lithium-Based Batteries through Economical
Chemistry. Chemistry of Materials 27 (1):37-43. doi:10.1021/cm502520y 30. Huang X, Cen D, Wei R, Fan H, Bao Z (2019) Synthesis of Porous Si/C Composite Nanosheets from Vermiculite with a Hierarchical Structure as a High-Performance Anode for Lithium-Ion Battery. ACS applied materials \& interfaces 11 (30):26854-26862. doi:10.1021/acsami.9b06976 31. Wang H-g, Yuan C, Zhou R, Duan Q, L i Y (2017) Self-sacrifice template formation of nitrogen-doped porous carbon microtubes towards high performance anode materials in lithium ion batteries. Chemical Engineering Journal 316:1004-1010. doi:10.1016/j.cej.2017. 02.059

32. Zhang SS, Xu K, Jow TR (2006) EIS study on the formation of solid electrolyte interface in $\mathrm{Li}$ ion battery. Electrochimica Acta 51 (8-9):16361640. doi:10.1016/j.electacta.2005.02.137 33. Shi Q, Wu X, Chen S, Wu X, Liu J, Long R (2020) Carbon-nitrogen quantum dots modification of Li4Ti5O12 anode material for lithium-ion batteries. Ionics 26 (7):3325-3331. doi:10.1007/s11581-020-03516-6 
Figures

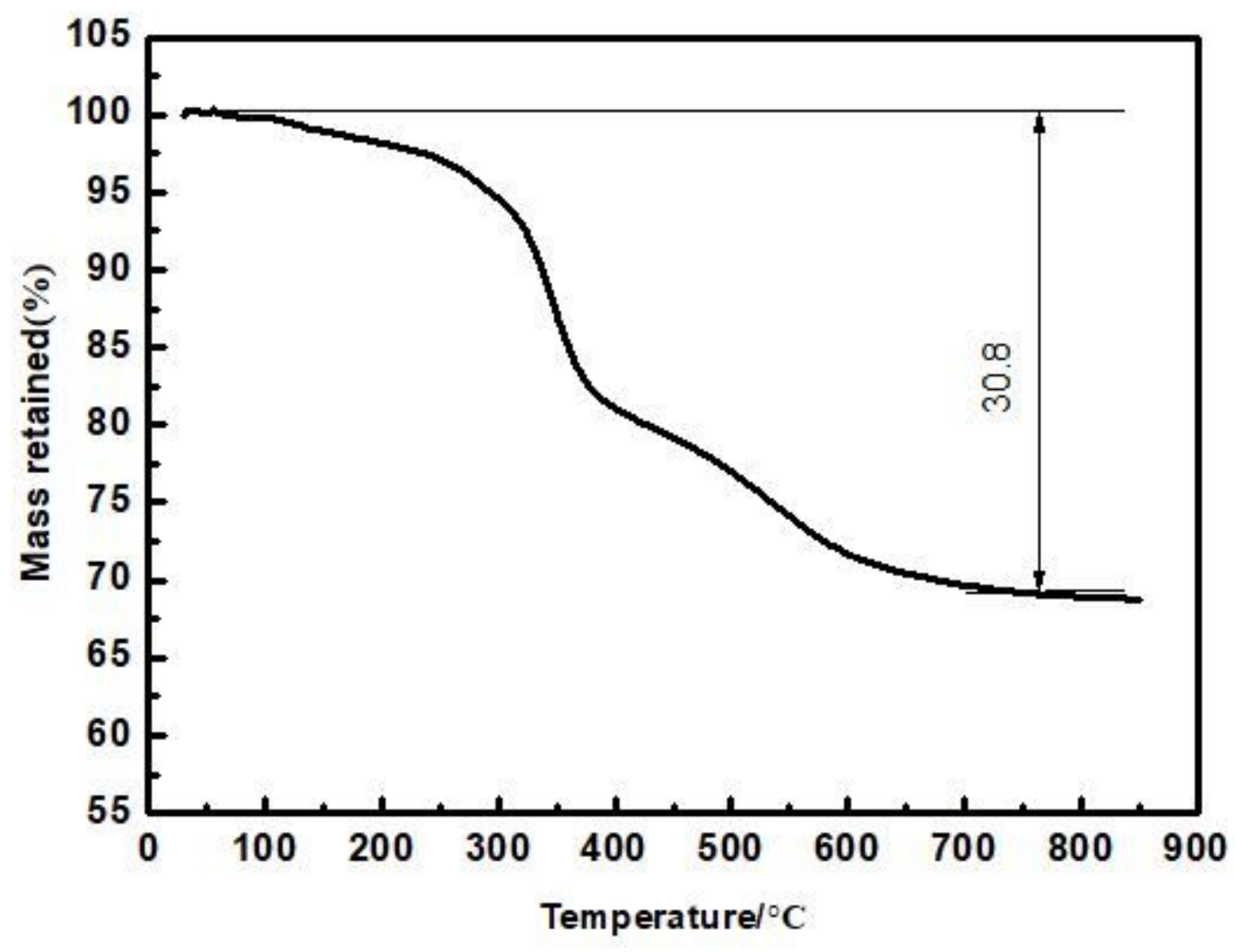

Figure 1

TG curves of the as-prepared Si/C composite 


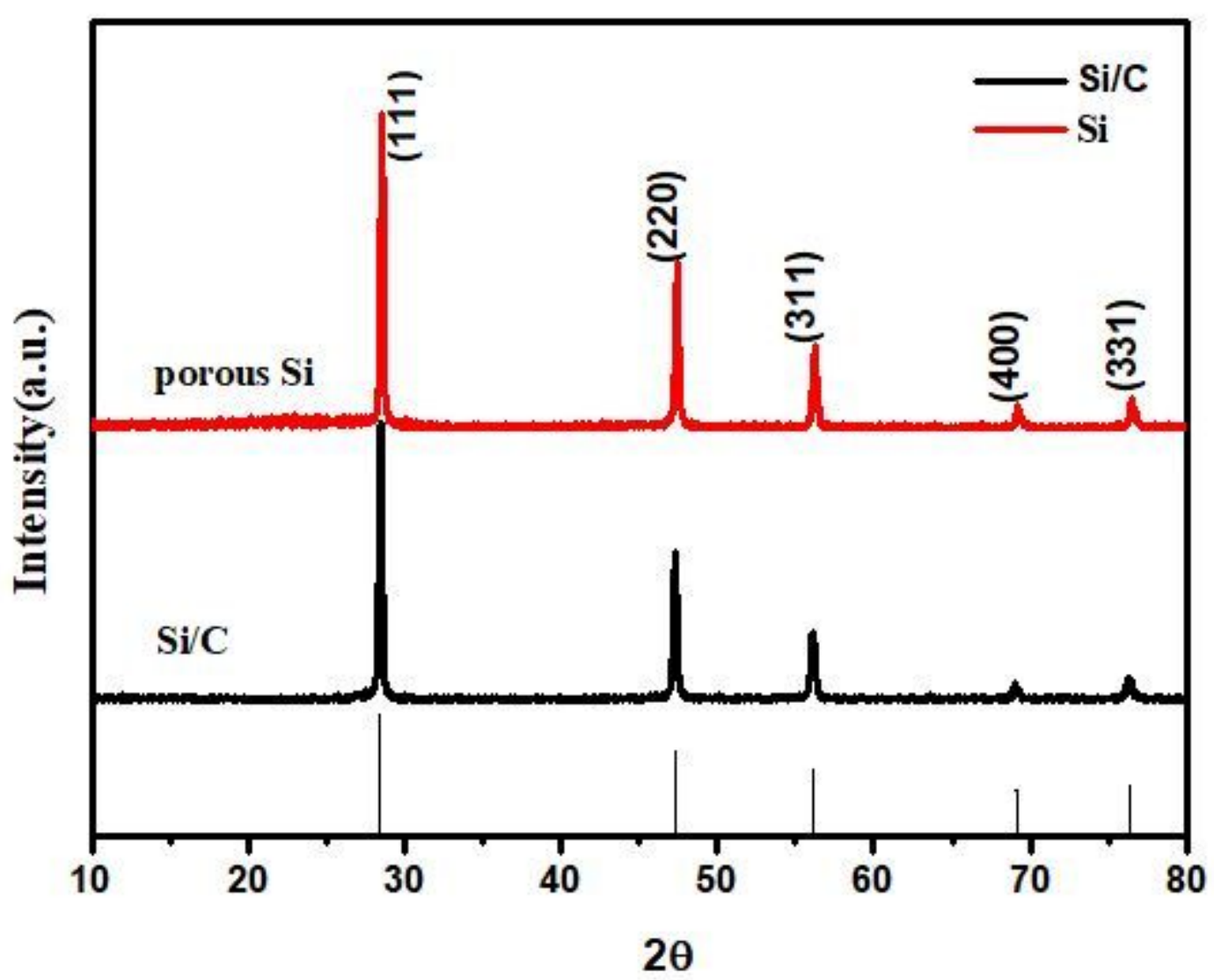

Figure 2

XRD patters of the porous silicon and Si/C composite
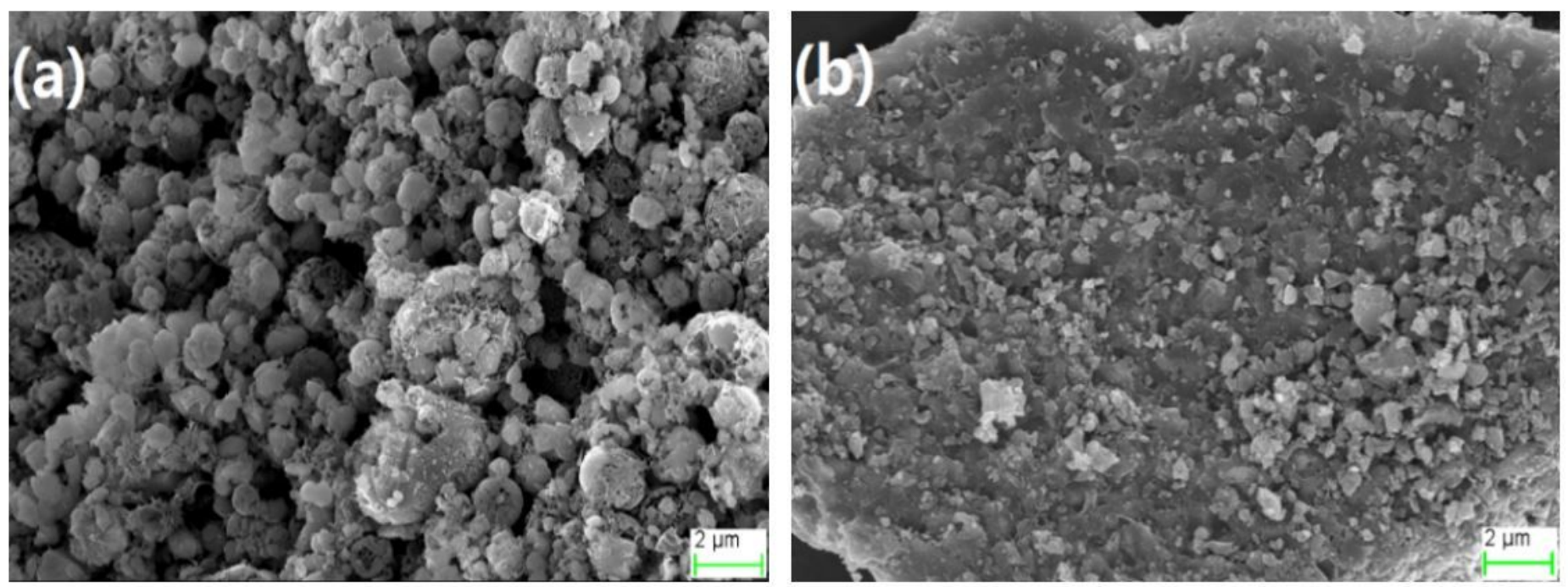

Figure 3

The scanning electron microscopy of porous Si and Si/C: (a) porous Si; (b) Si/C 

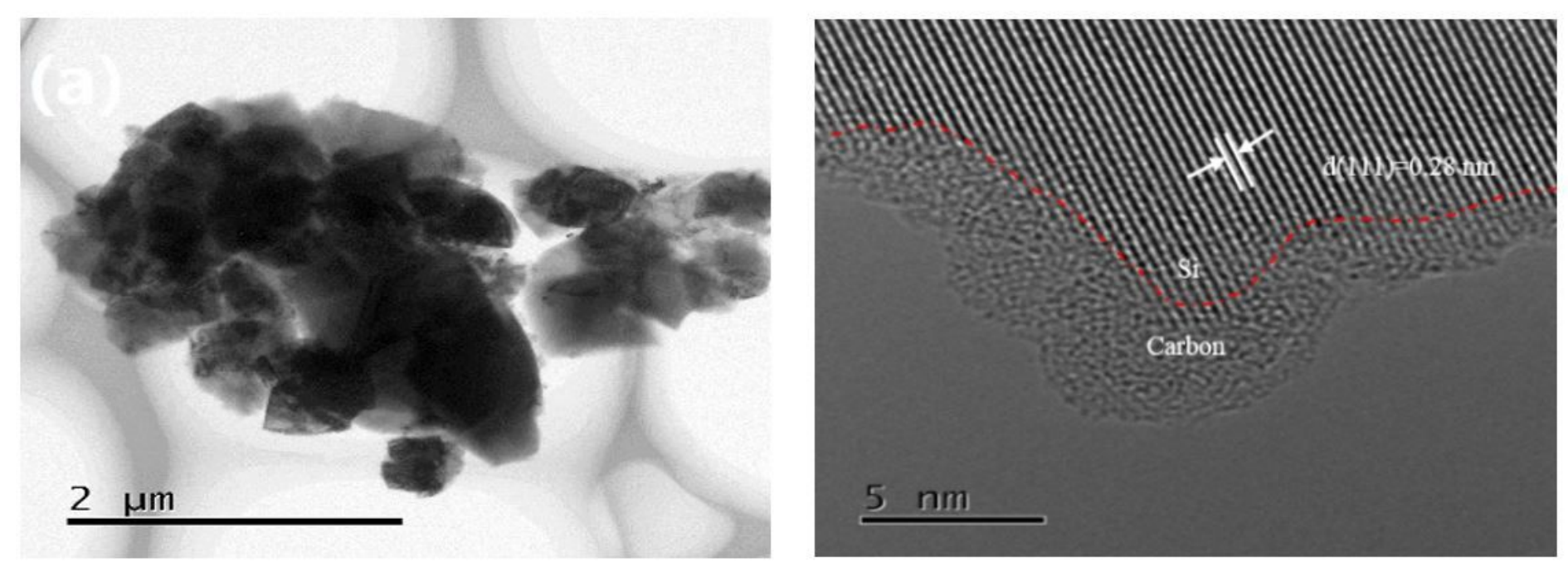

Figure 4

transmission electron micrographs images of Si/C
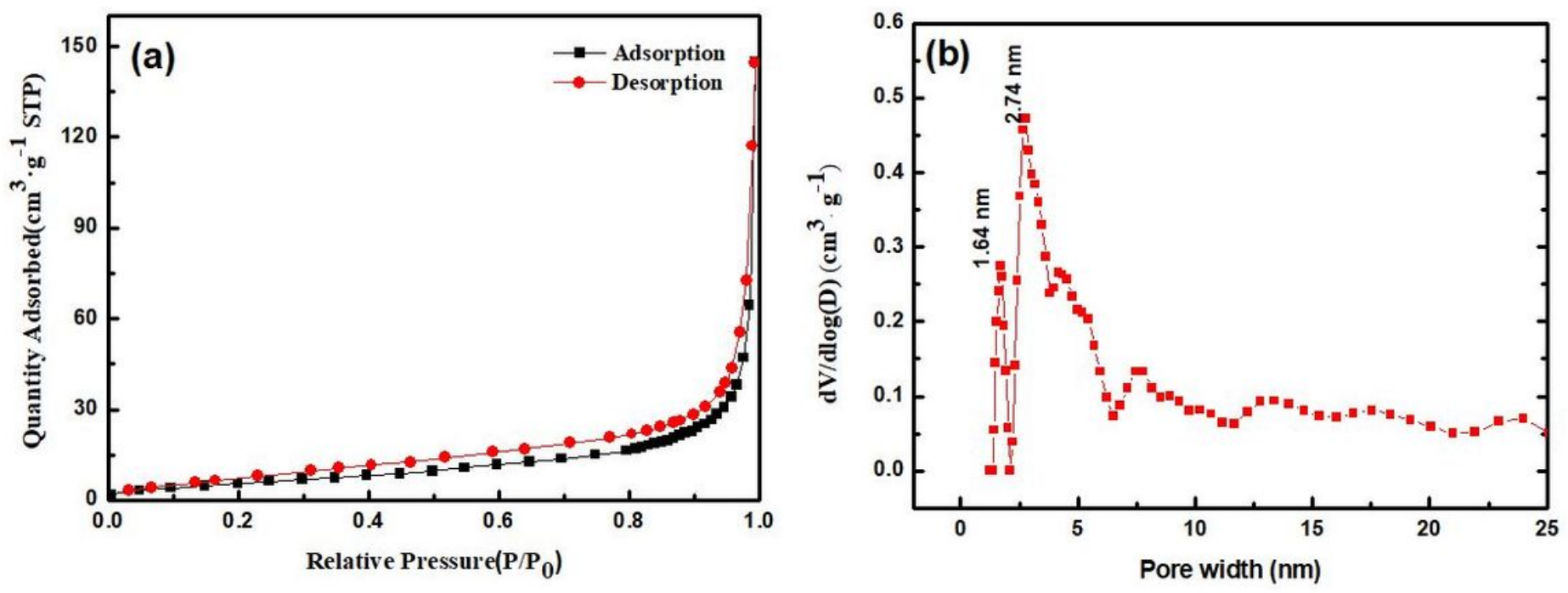

Figure 5

BET specific surface area test of Si/C composite (a) N2 adsorption-desorption isotherms;(b) DFT pore size distribution 

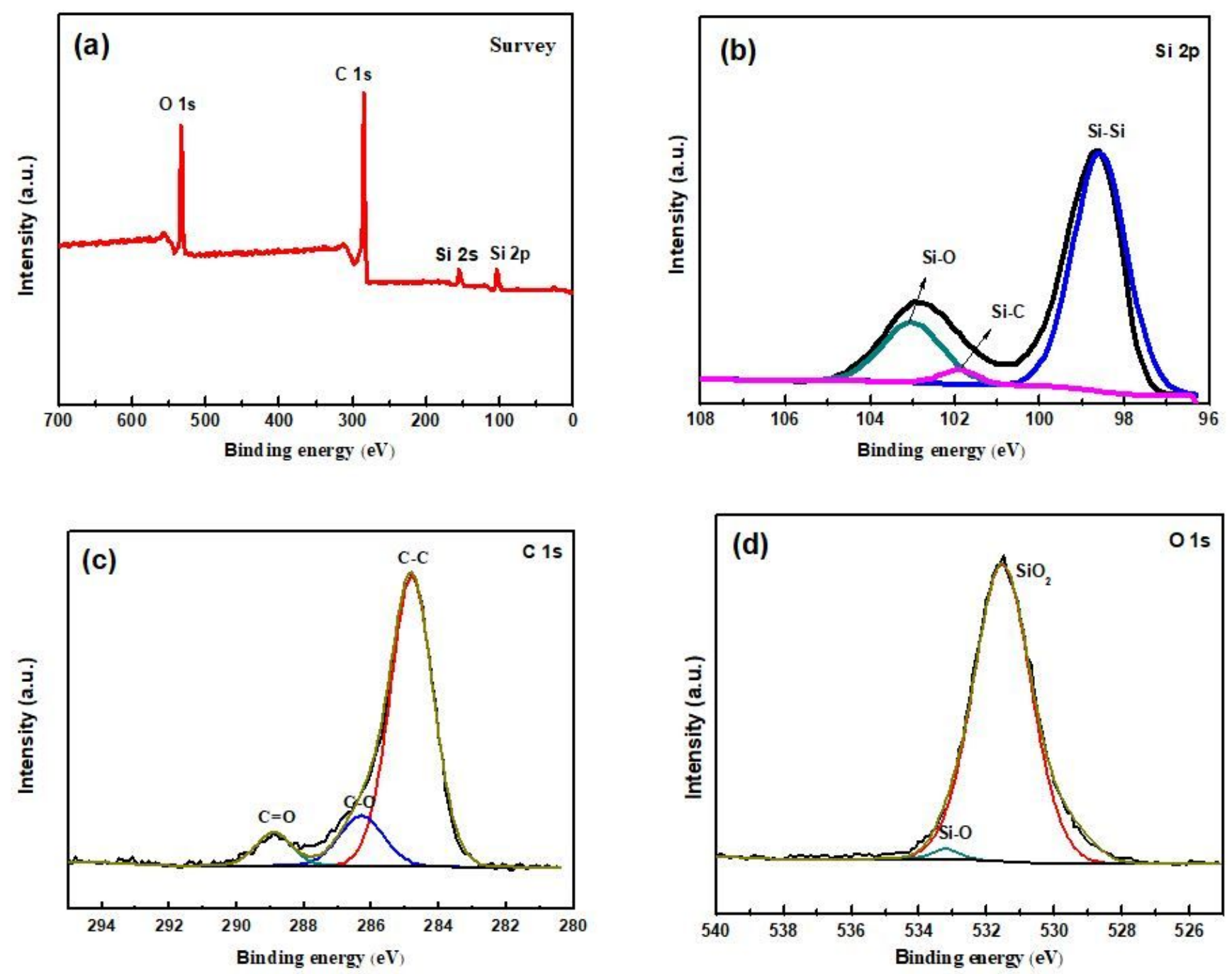

Figure 6

XPS spectra of porous Si and Si/C: (a)XPS spectra of porous Si and Si/C; (b) Si 2 p peaks of Si/C; (c) C 1 s peaks of $\mathrm{Si} / \mathrm{C}$; (d) 01 s peaks of $\mathrm{Si} / \mathrm{C}$ peaks of $\mathrm{Si} / \mathrm{C}$
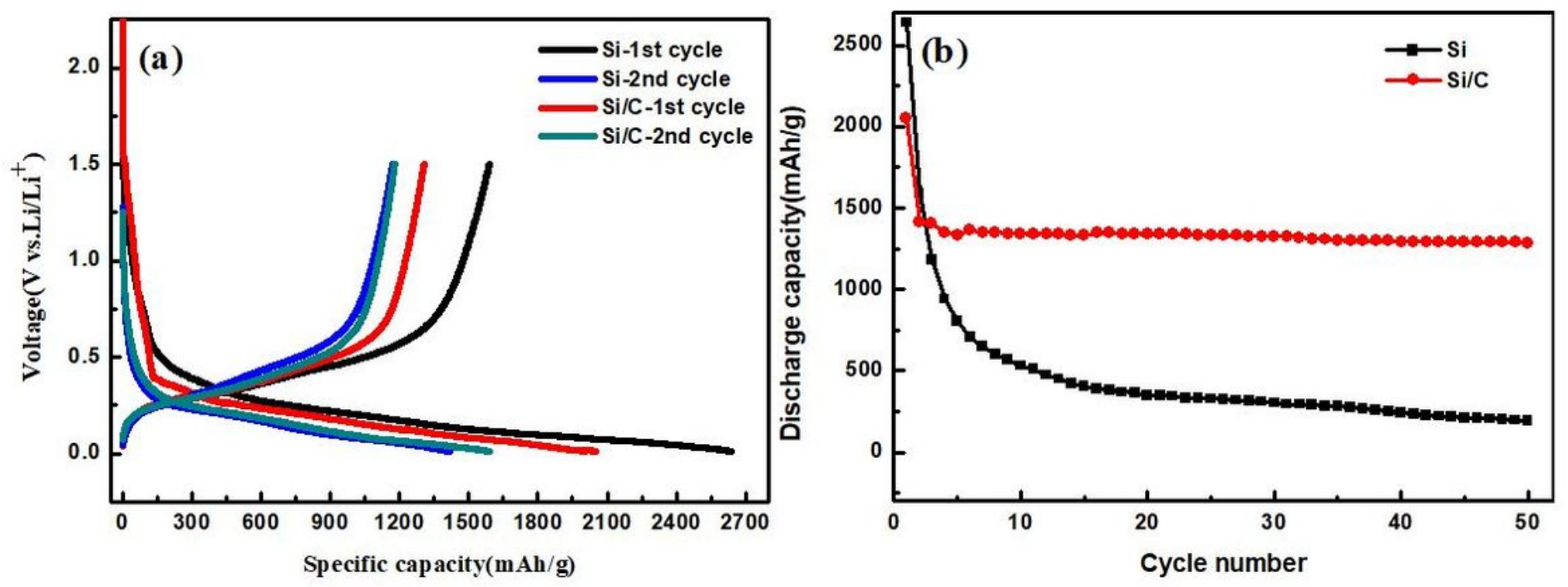
Figure 7

The electrochemical performances of porous $\mathrm{Si}$ and $\mathrm{Si} / \mathrm{C}$ at the current density of $0.1 \mathrm{~A} / \mathrm{g}$. (a) chargedischarge curves; (b) cycling performance

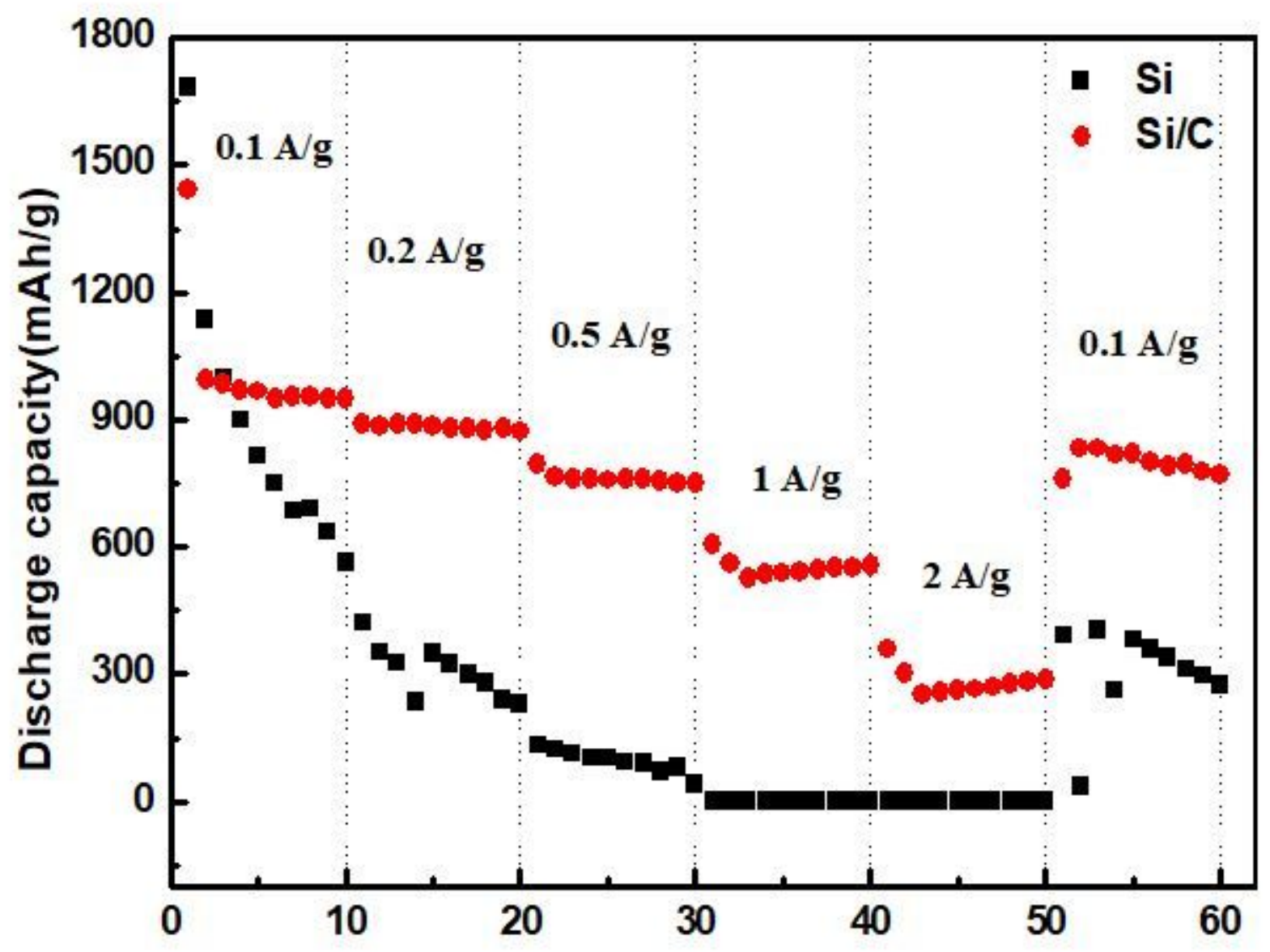

Cycle number

Figure 8

The cycling performances of porous $\mathrm{Si}$ and $\mathrm{Si} / \mathrm{C}$ at different charge-discharge rates 

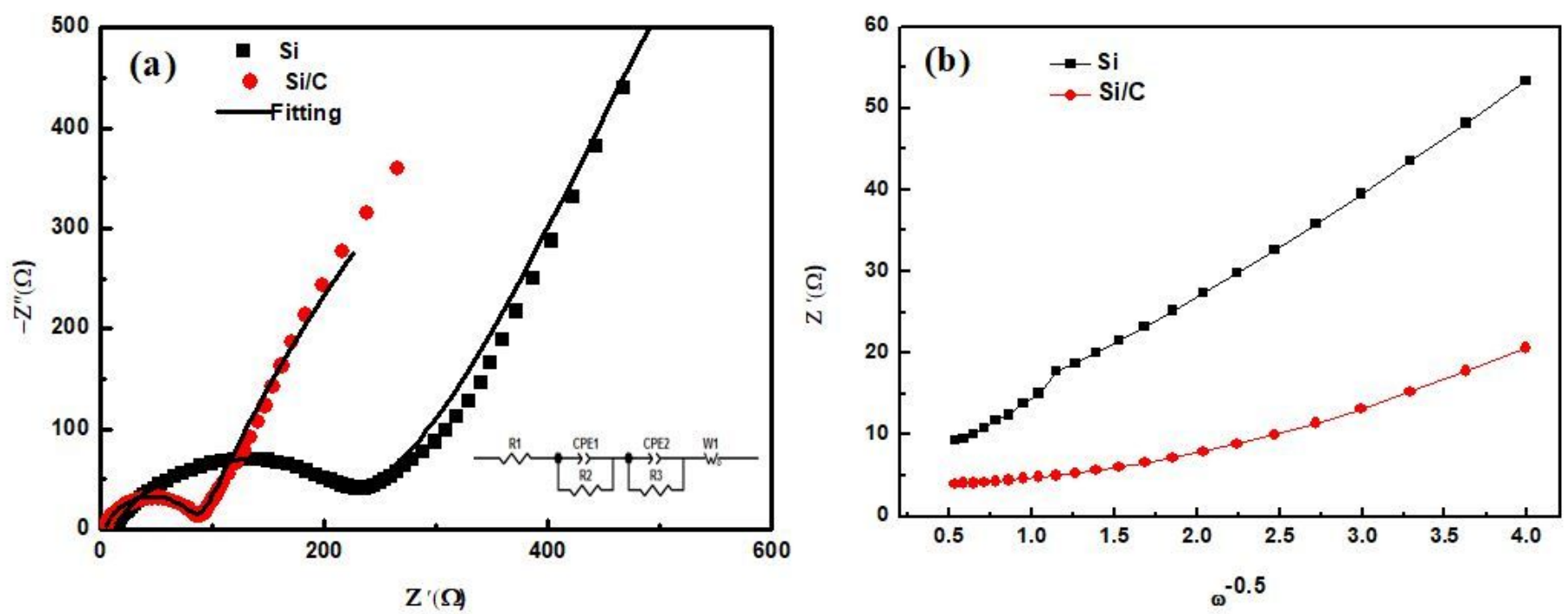

Figure 9

Electrochemical impedance spectra of porous Si and Si/C. (a) EIS curves of porous Si and Si/C; (b) the relationship of $Z^{\prime}$ and $\omega-0.5$ 